\title{
Sociální politika napříč národními státy
}

\section{Pauli Kettunen, Klaus Petersen (eds.): Beyond Welfare State Models: Transnational Historical Perspectives on Social Policy}

Cheltenham, Northampton, Edward Elgar 2011, 264 s.

O problematice sociálního státu a sociální politiky existuje nepřeberné množství různě koncipovaných studií, přičemž samotný komparativní výzkum v dané oblasti představuje specifické odvětví společenskovědní produkce. Nesporný význam srovnávacích přístupů pro rozvoj poznání i řešení praktických politických problémů motivoval badatele k hledání a vytváření vhodných analytických nástrojů. Značnou popularitu získalo díky svému heuristickému potenciálu používání modelů, které tak po dlouhou dobu představují standardní nástroj komparativního výzkumu sociálního státu. Současně se ale stále výrazněji ozývají kritické hlasy upozorňující na nedostatky tohoto přístupu. K nim lze zařadit i sborník editovaný Pauli Kettunenem a Klausem Petersenem [2011a].

V literatuře [např. Rákosník 2009] lze rozlišit v zásadě tři různá, avšak navzájem se doplňující pojetí sociálního státu: institucionální (sociální stát chápán jako institucionální uspořádání, jehož prostřednictvím stát rozděluje peníze, věci a služby svým občanům), kvantitativní (existence sociálního státu odvozována od výše veřejných sociálních výdajů) a normativní (sociální stát zahrnuje představu společného dobra - politického cíle, $\mathrm{k}$ němuž by měla směřovat činnost jeho institucí).

Na normativním pojetí je založena dnes již klasická a v českém prostředí téměř hegemonní typologie sociálního státu Gøsty Esping-Andersena [1990]. Podle ní lze západoevropské sociální státy rozdělit do tří ideálnětypických režimů: liberální, kladoucí dưraz na tržní řešení a selektivní sociální politiku (anglosaské země), konzervativní, spoléhající na tržní výkon a ochranu statusu (kontinentální evropské země), a sociálnědemokratický, založený na komplexní a státem poskytované univerzalistické sociální politice (severské země). Esping-Andersenova typologie modelových režimů byla kritizována v několika ohledech. Feministická kritika zdůrazňovala zanedbání odlišností mezi ideologiemi rodiny a rolí žen v poskytování neformální péče. Rozsáhlé debaty se rovněž vedly o zařazení jednotlivých zemí do př́íslušných skupin i o míře jejich vnitřní podobnosti, stejně jako o vhodnosti aplikace tohoto přístupu na nezápadní země. Esping-Andersen [1999] reagoval na tuto kritiku začleněním dimenze (de)familizace a návrhem středomořského režimu sociálního státu. Podobně Johan DeDeken [1992] použil pro východoevropské země v poválečném období koncept leninského režimu.

Výše zmíněná kritika se soustředí především na obsahové dimenze modelu či jeho aplikaci na konkrétní případy, nedotýká se však samotného užití modelů jako analytického nástroje. Základním východiskem recenzované knihy [Ket- 
tunen, Petersen 2011b: 1] je naproti tomu teze, že modely používané v komparativním výzkumu sociálního státu jsou statickými nástroji, v jejichž rámci národní státy a národní společnosti představují jednotky výzkumu jednoduše pokládané za dané (metodologický nacionalismus). Historie se tak stává synonymem vlastností národního vývoje, jeho kontinuity a závislosti na předchozím vývoji (pro překlad termínu path dependency dále užívám spojení „cesta závislosti“). Autoři zpochybňují použití modelio jako analytického rámce pro výzkum sociálního státu a současně zdůrazňují význam zkoumání politických, ekonomických a kulturních praktik napříč různými zeměmi. Konkrétně to zahrnuje roli mezinárodních institucí, sociálních hnutí, náboženství, krizí, šíření idejí, definic problémů (včetně agenda setting) i jejich řešení, které překračují národní hranice.

Tuto kritiku je možné aplikovat také na hlavní př́istupy k vysvětlení geneze vývoje sociálního státu včetně odlišností jeho podob v jednotlivých zemích. Již od sedmdesátých let se rozvíjí přístup vysvětlující vznik sociálního státu v návaznosti na tradici strukturního funkcionalismu a teorie modernizace na principu logiky industrializace, podle níž se sociální stát objevuje jako reakce na demografické a sociální dopady procesu industrializace (např. Wilensky [1975] zkoumá strukturální předpoklady sociálních výdajů v jednotlivých zemích). Alternativní konfliktualistický přístup, vycházející z marxismu a teorie konfliktu, zdůrazňuje význam rozporu mezi prací a kapitálem, který se projevuje ve formě politického tř́ídního boje. Míra rozvoje sociálního státu závisí na schopnosti mobilizace levicových sil (politických stran i odborů). Sem patří mimo jiné teorie mocenských zdrojů Waltera Korpiho [1983]. Odlišný pohled na stát představuje institucionální pohled, který zdůrazňuje roli státní byrokracie jako samostatného aktéra, význam kapacity státní administrativy a míru disperze moci, stejně jako strukturu základní sady státních programů sociální politiky před jejich expanzí [např. Weir, Orloff, Skocpol 1988].

U všech těchto přístupů lze najít společný jmenovatel v podobě metodologického nacionalismu, nebot' pro vztah mezi stupněm industrializace a výší sociálních výdajů i zkoumání kapacity státní administrativy a role byrokracie představuje národní stát nutně výchozí analytický rámec i jednotku analýzy. Role mobilizace levicových sil je rovněž uvažována v kontextu jednotlivých národních států, které jsou následně porovnávány mezi sebou. Takto pojaté výklady vývoje vedou v debatách o sociálním státu podle Kettunena a Petersena [2011b: 4-9], stejně jako třeba Esping-Andersenův model, ke specifickým zkreslením v chápání historie, která je nutné korigovat či překonat.

Za prvé se jedná o jev typický i pro veřejné debaty, že se „historie“ stává téměř synonymem pro specifické národní zvláštnosti. Ve srovnávacích výzkumech i v analýzách vlivu globalizace (a často i EU) na sociální stát představuje výchozí bod rozlišení mezi aktérem a vnějším prostředím, kdy se aktér (konkrétní národní stát) musí nějak adaptovat či bránit změnám v tomto prostředí. Podle obou autorů však hrály konstitutivní roli při utváření národních sociálních států mezinárodní a transnacionální procesy, které se stejně jako globalizace neodehrá- 
vají pouze ve vnějším prostředí společností národních států, ale také uvnitř nich prostřednictvím národocentrických způsobů myšlení a jednání.

Za druhé jde o představu historie jako počátku, kdy se historici snaží hledat kořeny či moment vzniku sociálního státu. Nelze však předpokládat, že nalezení počátku nějakého jevu zahrnuje i jeho vysvětlení. Rovněž je sporné, do jaké míry má být daný jev vysvětlen. Navíc se v takto pojatém výzkumu často objevuje určitá podoba nereflektovaného teleologického prezentismu. Namísto hledání počátku je proto třeba vycházet $\mathrm{z}$ přístupu zaměřeného na mnohovrstevnatou historicitu sociálního státu, který bere v úvahu přítomnost odlišných institucionálních a diskurzivních vrstev rozvinutých v různých časových obdobích. Analytická představa mnohovrstevnatosti pomáhá dekonstruovat lineární obrazy změny, které se často objevují ve výzkumu sociální politiky.

Za třetí se kritika obou autorů týká př́liš zjednodušeného pojetí historie jako "cesty závislosti“. Historicitu je naproti tomu třeba chápat jako institucionální a diskurzivní podmíněnost umožňující i omezující jednání a současně vnímat nejistotu a otevřenost jednání a horizontu očekávání. Kombinace kontingence i cesty závislosti zahrnuje kontinuitu i zlomy, předpoklady i omezení institucionálních inovací. Komparativní výzkum by se proto měl soustředit na kulturní a politické transfery nejen mezi předem danými jednotkami v podobě národních států, ale také na transfery, překlady, interakce a překračování či křížení jako konstitutivní praxi při formování stran v rámci těchto vztahů.

Zmíněné principy tvoří základní pilíře transnacionálního př́stupu, vznikajícího jako reakce na nedostatky stávajících modelů a komparativních výzkumů sociálního státu. Za klasický př́klad studie vývoje sociální politiky z transnacionální perspektivy bývá považována práce Daniela T. Rodgerse Atlantic Crossings: Social Policy in a Progressive Age [1998]. Rodgers navazuje na tradici atlantických dějin, rozvíjenou již od padesátých let i díky snaze vítězných západních mocností integrovat své dějinné příběhy do jediného. Problematika atlantického prostoru bývá studována $\mathrm{v}$ kontextu hospodářského vývoje regionu či dějin moderního otroctví [Kř́̌žová 2005], sociální politika se stala předmětem studia v rámci tohoto přístupu v pozdejjším období. Rodgers si ve své obsáhlé studii klade několik otázek: jak se zrodila a jak byla udržována éra transatlantické sociální politiky, jaký vliv měla sít transnacionálních vazeb, do jaké míry formovala politické volby a do jaké míry podobné či odlišné se retrospektivně jeví Spojené státy oproti svým nejbližším evropským protějškům. Prostřednictvím zkoumání událostí a procesů, politiky i idejí v prostoru severoatlantické ekonomiky se autor pokouší posunout hranice a rámec tradičního příběhu o výjimečnosti národního vývoje USA. [Rodgers 1998: 7]

Studie z oblasti výzkumu severského či skandinávského modelu sociálního státu bývají obvykle strukturovány na principu samostatných studií o situaci v jednotlivých zemích a následného srovnání podobností a odlišností [např. Brochman, Hagelund 2012], případně se zaměřují na jednotlivé tematické oblasti, v jejichž rámci porovnávají podobnosti a odlišnosti vývoje $\mathrm{v}$ jednotlivých 
zemích [např. Kautto et al. 2002]. V obou případech však národní stát představuje základní rámec i jednotku analýzy, z čehož pochopitelně vyplývají i omezení spjatá s metodologickým nacionalismem. Patrně první systematičtější pokus o výklad vývoje severského sociálního státu z transnacionální perspektivy představuje práce kolektivu autorů [Christiansen et al. 2006], která se zaměřuje vedle metodologických otázek na rozbor vývoje jednotlivých oblastí sociální politiky $\mathrm{v}$ průběhu dvacátého století (pojištění v nezaměstnanosti, starobní penze, rodinná politika, zdravotnictví, participace žen na trhu práce) a spolupráci severských zemí v oblasti sociální politiky v první polovině dvacátého století a v době krize severského modelu sociálního státu.

Recenzovaná publikace má s touto knihou společná teoretická východiska (historický a transnacionální př́ístup) i obecné téma (severský model sociálního státu). Věnuje ovšem výraznější pozornost metodologickým otázkám a obecnějším otázkám sociální politiky, severského modelu, roli náboženství, genderové problematice, konceptu sociálnědemokratického blahobytného kapitalismu i konkrétněji normativním aspektům marketizace sociálních služeb.

V úvodní části [Kettunen, Petersen 2011b] autoři předkládají námitky vůči tradičním modelům a komparativním výzkumům sociálního státu a základním principům transnacionálního př́istupu (viz výše). Nejedná se však o novou teorii vývoje sociálního státu, nýbrž pouze o snahu otevř́t nové otázky a perspektivy a vymezení základního rámce interdisciplinárního výzkumu, v jehož rámci by měly být zkoumány.

Kettunen [2011] zkoumá sociální státy v severských zemích jako transnacionální historické konstrukce. Ve svém příspěvku se soustředí na vývoj uchopení „sociální otázky“, který sleduje od počáteční fáze, z hlediska vztahu periferiecentrum v modernizující se společnosti národního státu koncem devatenáctého století, k době globalizovaného kapitalismu s rostoucí ekonomickou a společenskou asymetrií $\mathrm{s}$ dưrazem na prostorové vazby. Tyto asymetrie působí ve směru posunu od tradičního souladu mezi společenskou rovností, ekonomickým růstem a rozšiřováním demokracie k nové konstrukci národní identity, ovlivněnou snahou o konkurenceschopnost národního společenství. Staré instituce sociálního státu se tak přizpůsobují imperativu konkurenceschopnosti, což zahrnuje i proplétání starého a nového pojetí sociálna, zejména s ohledem na roli práce.

V následující studii se Klaus Petersen [2011] zaměřuje na formování severského modelu sociálního státu jako procesů na národní, severské i mezinárodní úrovni. Sociální stát je sice historicky zakotven v národním státu, avšak jeho národní podoby i transnacionální koncept severského modelu byly ovlivněny spoluprací, komunikací, vnitřní rivalitou, vzájemnou závislostí, nápodobou a výměnou idejí mezi jednotlivými zeměmi regionu. Jeho vývoj, včetně pozice a role jednotlivých zemí i jejich národního vývoje, byl vždy v řadě ohledů podmíněn širšími mezinárodními a transnacionálními vlivy (např. myšlenky a praktiky sociální politiky, globální ekonomika, nadnárodní instituce a sítě), které se tak staly jeho součástí. 
Stein Kuhnle [2011] ukazuje, jak se řešení „sociální otázky“ v severských zemích koncem devatenáctého století utvářelo v mezinárodním kontextu, který se vyznačoval měnícími se národními státy a produkcí a šířením vědění, myšlenek a modelů, jejich transfery, přizpůsobením, modifikacemi i odmítáním. Pro porozumění institucionálním a normativním vlastnostem severských sociálních států je třeba $v$ historické perspektivě zkoumat, jak jednotliví aktéři chápali domácí sociální a politické problémy a jaký byl vliv vnějších událostí, aktérů a idejí na nová politická řešení. Zavedení národních systémů sociální bezpečnosti nelze vysvětlovat pouze s ohledem na míru modernizace a industrializace (viz perspektiva logiky industrializace), ale je třeba vzít úvahu i kapacitu státní administrativy, včetně statistických institucí (institucionální pohled).

Všechny tyto dílčí studie se zaměřují na problematiku utváření severského modelu sociálního státu a pohledy na řešení „sociální otázky“ coby jednoho z klíčových problémů modernizace. Ketunnen se soustředí na vliv změn globalizovaného kapitalismu na formování kolektivní identity a normativní a ideologické aspekty severského sociálního státu, Klaus Petersen analyzuje procesy a interakce idejí, institucí a aktérů při formování severského sociálního státu na úrovni národní, regionální a mezinárodní a Kuhnle se věnuje šíření idejí a konceptů v měnícím se prostředí, jeho porozumění ze strany historických aktérů a aplikaci v rámci politických řešení, tedy formování normativních a institucionálních specifik severského modelu sociálního státu. Transnacionální perspektiva tedy autorům umožňuje uchopit severský model v jeho základních dimenzích (institucionální i normativní, kvantitativní zde stojí v pozadí) i ve vztahu k makrosociálním procesům (vývoj globalizovaného kapitalismu, formování národního státu).

Ze své podstaty transnacionální charakter mají zejména velká náboženství, jakkoli jejich vliv na formování a podobu sociálního státu dosud není dostatečně prozkoumán. Z pohledu Keese van Kersbergena [2011] způsobuje stále dominantní „,sociálnědemokratický model vysvětlení", zdůrazňující roli hnutí pracujících a levicových stran, opomíjení mnohostranného vlivu náboženství na sociální stát (obsah víry a role teologických doktrín, organizované aktivity církví a farností, dopad náboženství jako kulturní síly, vliv nábožensky inspirovaných politických hnutí typu křestanské demokracie a rozsah makrosociálních procesů typu modernizace či sekularizace). Autor se tak pokouší o kulturalistickou korekci výzkumu sociálního státu v podobném smyslu, jakým Max Weber doplnil Marxovu teorii vzniku kapitalismu o roli protestantské etiky. Van Kersbergenova kritika však není zcela přesná, nebot nap̌r. jeden z hlavních představitelů „sociálnědemokratického" proudu - Walter Korpi [1983] - uvažuje význam vztahu státu a církve pro formování linií politických konfliktů, a tedy i mobilizaci hnutí pracujících a vznik křestáanskodemokratických stran. Právě politická hnutí redefinující náboženské sociální doktríny představovala podle van Kersbergena hlavní formu přímého vlivu náboženství na sociální stát.

Jestliže van Kersbergen se soustředil především na katolicismus a jeho sociální nauku, Pirjo Markkola [2011] se zaměřil na roli luteránství v historii sever- 
ských sociálních států. Některé výklady vykreslují kontinuální vývoj od reformace k dnešnímu severskému modelu a spojují luteránský odkaz se základními rysy severského modelu (rovnostářství, plná zaměstnanost, silný stát i silný individualismus). Takto pojatý lineární vývoj a z něj vyplývající označení severských sociálních států jako sekularizovaného luteránství však je třeba vzhledem k nedostatečné rozpracovanosti problematiky náboženských dimenzí sociální politiky teprve historicky testovat.

Na rozdíl od náboženství představuje genderová problematika a rodinná politika poměrně frekventovanou oblast v rámci výzkumu sociálního státu. Sonya Michel [2011] argumentuje, že vzhledem k historické proměnlivosti pojmu rodina, mnohdy nezamýšleným formám i důsledkům rodinné politiky překračujícím národní rámec, je třeba zaměřit výzkum „režimů rodinné politiky“ na transnacionální vazby a způsoby, jakými se velké transnacionální transformace projevují v odlišných národních a regionálních kontextech. Autor proto nabízí periodizaci vývoje tohoto vztahu v rámci západního kulturního okruhu od rodiny jako bašty nově vznikajících národů v "dlouhém devatenáctém století“ přes rodinu jako předmět zájmu nově se rozvíjejících humanitních, sociálních a behaviorálních věd za první světové války a v meziválečném období, rodiny jako zdroje morálky i obav za druhé světové války a v poválečném období, vnitřní výzvy rodiny kolem roku 1968 a později až po vnější výzvy rodiny v době neoliberalismu a globalizace.

Př́padovou studii transnacionalizace rodinné politiky na př́kladu severské reformy manželství z počátku dvacátého století představuje práce autorek Kari Melby, Anny-Birte Ravn, Bente Rosenbeck a Christiny Carlsson Wetterberg [2011]. Na rozdíl od ostatních zemí se severské reformy manželství vyznačovaly již v tomto období liberalizací rozvodu, ekonomickou rovností mezi mužem a ženou i vědeckým a sekularizovaným chápáním manželství, kombinujícím státní intervenci s individualismem. Reforma manželství vyplynula ze vzájemné komunikace a spolupráce severských zemí a souvisela s národním zájmem o zdraví populace a sociální politikou zaměřenou na prevenci sociálních problémů spíše než na jejich kompenzaci.

Christopher Lloyd [2011] zdůrazňuje nutnost zkoumat ve vývojové perspektivě „,sociálnědemokratický blahobytný kapitalismus“, vyznačující se specifickou konstelací společensko-ekonomicko-politických vztahů (kombinace liberalismu, sociální spravedlnosti, rozvinutého sociálního státu, kolektivní regulace práce a kapitalistických ekonomických imperativů). Většina hlavních politických stran $\mathrm{v}$ západních zemích $\mathrm{v}$ poválečném období tento model více či méně akceptovala, dnes se však tento model ocitá pod tlakem globalizovaných trhů, fiskální krize a nových typů lidových hnutí, což z autorovy perspektivy představuje radikalizaci některých modernizačních tendencí směrem $\mathrm{k}$,"ultramodernitě“.

Zmíněné „ultramodernizační" tendence zahrnují od osmdesátých let i obrat k neoliberalismu, důrazu na trh a individuální volbu, jehož dopady zkoumá Jorn Henkrik Petersen [2011] na příkladu debat o organizaci péče o starší a handica- 
pované občany ve Švédsku a v Dánsku. Na neoliberální zpochybnění legitimity této významné součásti sociální politiky univerzalistického sociálního státu zareagovali sociální demokraté akceptováním principu konkurence a svobodné volby, avšak pouze $v$ rámci veřejného sektoru. Nerealizovali žádné kroky k přizpůsobení těchto služeb trhu, současně ale neusilovali aktivně o vytvoření přesvědčivé argumentace proti základní ideji protržních reforem.

V závěrečné kapitole shrnuje Christoph Conrad [2011] důsledky "transnacionálnúho obratu“ pro společenskovědní a historický výzkum sociální politiky, který vyvolala nespokojenost s dosavadními komparativními výzkumy spíše petrifikujícími situaci v rámci jednotlivých národních států namísto uvažování vzájemných vztahů a interakcí mezi jednotlivými prvky komparace. Národní státy však nadále zůstávají rozhodujícími aktéry sociální politiky a klíčovým problémem zůstává postižení inherentního vztahu mezi transnacionálními souvislostmi a trvalou, i když proměňující se rolí národního státu. Autor rozlišuje několik „vektorů transnacionality“ objevujících se napříč různými tématy výzkumu sociální politiky: cirkulace modelů, organizace a fóra transnacionalizace, komunity a sítě expertů, překlady, pohybliví aktéři, transnacionální právo a normy, pohyb financí a vzájemná mezilidská podpora a globální sociální politika.

Toto poněkud obsáhlejší představení jednotlivých kapitol recenzované publikace může posloužit jako ilustrace širokých možností aplikace transnacionálního př́stupu k výzkumu sociální politiky, sahající od vlivu náboženství přes rodinnou politiku až ke konstelacím společensko-ekonomicko-politických vztahů v rámci kapitalismu. Transnacionální přístup umožňuje oproti tradičním modelům zkombinovat $\mathrm{v}$ rámci analýzy současně normativní, institucionální a v zásadě i kvantitativní dimenzi sociálního státu, byť posledně jmenovaná zůstala $\mathrm{v}$ této práci pouze naznačena poukazy na ekonomické souvislosti v podobě fiskální krize či neoliberalismu. Transnacionální př́istup v principu nevylučuje pohled na genezi sociálního státu z hlediska logiky industrialismu, institucionální perspektivy i konfliktualistického přístupu zdưrazňujícího význam politického třídního boje, avšak spíše než o jejich syntézu, která je vzhledem k odlišným teoretickým východiskům jednotlivých perspektiv v praktickém výzkumu obtížná, usiluje o překonání jejich limitů vyplývajících z jejich základních předpokladů i metodologického nacionalismu. Transnacionální přístup v pojetí autorů této knihy netvoří ucelenou teorii, nýbrž spíše perspektivu či širší rámec pro historický a komparativní výzkum sociální politiky a sociálního státu umožňující plastičtěji postihnout pestrou škálu různorodých sociálních vztahů a interakcí i vývojových nuancí. Jestliže transnacionální přístup vznikl jako reakce na nedostatky metodologického nacionalismu, obsahuje na druhé straně riziko, jakkoli si ho autoři uvědomují, přecenění vlivu vnějších faktorů na vývoj jednotlivých zemí. Navíc takto pojatý přístup sice redukuje riziko přizpůsobování reality výchozím abstraktním modelům, ze stejných prŕččin ale může ztrácet ze zřetele některé hlubší strukturní či globální souvislosti.

Na ně se naopak zaměřuje teorie světového systému, kterou lze chápat rovněž jako specifickou variantu transnacionálního přístupu, byt' se její představi- 
telé problematice sociálního státu či sociální politiky věnují spíše okrajově. Podle Margo Nankoe [2002] je nezbytným předpokladem rozvoje sociálního státu existence dostatečně početného proletariátu (proto jsou rozvinutější sociální státy v zemích jádra a semiperiferie) a dostatečně asertivního hnutí pracujících (proto se sociální stát více rozvinul a zůstal odolnější vưči současným tlakưm na jeho omezení $\mathrm{v}$ zemích kontinentální západní a severní Evropy na rozdíl od anglosaských zemí). Teorie světového systému tak představuje variantu konfliktualistického přístupu z globální perspektivy (uvažuje roli antisystémových hnutí nejen v rámci národních států, ale i ve světovém systému jako celku), zahrnuje však i otázky industrializace a vzestupu jednotlivých zemí i roli státu (mj. s ohledem na pozici země v jádru, semiperiferii či periferii). Současně umožňuje zkoumat normativní aspekty sociálního státu v kontextu geokultury a dominantní ideologie světového systému, kvantitativní parametry v souvislosti s vývojem kapitalistické světové ekonomiky a v principu i institucionální strukturu (napřs šíření institucionálních inovací ze zemí jádra), jakkoli rozdílnosti konkrétních podob sociálního státu a sociální politiky v jednotlivých zemích dosud nebyla v rámci tohoto př́stupu věnována dostatečná pozornost. Tato varianta transnacionální perspektivy na druhou stranu obsahuje oproti pojetí $\mathrm{v}$ recenzované publikaci vyšší riziko přecenění významu vnějších faktorů pro národní vývoj či v dílčích otázkách schematizaci podle logiky teoretického modelu.

Pro čtenáře $\mathrm{v}$ českém jazykovém prostředí může být kniha přínosná nejen z hlediska rozboru zpracování některých otázek formování severského modelu sociálního státu či vztahu náboženství a sociální politiky, kterým je zde věnována minimální pozornost, ale zejména otevřením nových otázek vyplývajících z transnacionálního přístupu (výzkum sociálního státu na českém území se soustředí pouze na některé, např. sovětizaci sociálního státu v padesátých letech [Rákosník 2010; Rákosník, Tomeš 2012]): Jak se projevoval z hlediska idejí i praktické politiky německý vliv na sociální politiku na českém území a v ostatních částech Rakouska-Uherska v období monarchie i po získání nezávislosti? Jak se proměňoval vliv náboženství, zejména katolicismu, na sociální politiku a jakou roli sehrála lidová strana při utváření sociální a rodinné politiky (zejména za první republiky a po vzniku samostatné České republiky)? Jak se proměňoval a jakých odlišností v jednotlivých východoevropských zemích nabýval vliv Sovětského svazu v poválečném období? Jakým způsobem a do jaké míry ovlivnil po roce 1989 sociální politiku jednotlivých východoevropských zemí neoliberalismus a ekonomická globalizace? Jakou roli sehrály nadnárodní instituce typu Mezinárodního měnového fondu, Světové banky, Mezinárodní organizace práce a Evropské unie? Jakým způsobem a s jakým výsledkem působila na sociální politiku kooperace i rivalita mezi východoevropskými zeměmi (včetně česko-slovenských vztahů od roku 1993)? V jaké podobě se v podmínkách silně diskontinuitního domácího i mezinárodního politického vývoje ve dvacátém století projevila tendence k cestě závislosti nejen v oblasti institucí sociální politiky (princip sociálního pojištění), ale i jejích normativních aspektů a jaké jsou její předpoklady? 
Kniha autorského kolektivu pod vedením Kettunena a Petersena může tuzemskému čtenáři poskytnout nejen vhled do některých opomíjených témat sociální politiky, ale současně mu může nabídnout alternativní přístup k interdisciplinárnímu bádání $\mathrm{v}$ dané oblasti a inspirovat ho k výzkumu zasazenému do širšího regionálního či transnacionálního rámce.

Karel Hanuš

\section{Literatura}

Brochmann, G., A. Hagelund (eds.). 2012. Immigration Policy and the Scandinavian Welfare State 1945-2010. Basingstoke: Palgrave Macmillan.

Conrad, C. 2011. Social Policy Turn after the Transnational Turn. Pp. 218-240 in P. Kettunen, K. Petersen (eds.). Beyond Welfare State Models. Transnational Historical Perspectives on Social Policy. Cheltenham, Northampton: Edward Elgar.

DeDeken, J. J. 1992. „Sociální politika a politika solidarity.“ Sociologický časopis 28 (3): 351-368.

Esping-Andersen, G. 1990. The Three Worlds of Welfare Capitalism. Cambridge, Oxford: Polity Press, Blackwel Publishers Ltd.

Esping-Andersen, G. 1999. Social Foundations of Postindustrial Economies. Oxford: Oxford University Press.

Christiansen, N.-F., K. Petersen, N. Edling, P. Haave (eds.). 2006. The Nordic Model of Welfare: A Historical Reppraisal. Copenhagen: Museum Tusculanum Press.

Kautto, M., M. Heikkilä, B. Hvinden, S. Marklund, N. Ploug (eds.). 2002. Nordic Social Policy: Changing Welfare States. London, New York: Routledge.

Kersbergen, K. van. 2011. „From Charity to Social Justice: Religion and the European Welfare State Tradition." Pp. 82-101 in P. Kettunen, K. Petersen (eds.). Beyond Welfare State Models. Transnational Historical Perspectives on Social Policy. Cheltenham, Northampton: Edward Elgar.

Kettunen, P. 2011. „The Transnational Construction of National Challenges: The Ambiguous Nordic Model of Welfare and Competitiveness." Pp. 16-40 in P. Kettunen, K. Petersen (eds.). Beyond Welfare State Models. Transnational Historical Perspectives on Social Policy. Cheltenham, Northampton: Edward Elgar.

Kettunen, P., K. Petersen (eds.). 2011a. Beyond Welfare State Models: Transnational Historical Perspectives on Social Policy. Cheltenham, Northampton: Edward Elgar.

Kettunen, P., K. Petersen. 2011b. „Introduction: Rethinking Welfare States Models.“ Pp. 1-15 in P. Kettunen, K. Petersen (eds.). Beyond Welfare State Models. Transnational Historical Perspectives on Social Policy. Cheltenham, Northampton: Edward Elgar.

Korpi, W. 1983. The Democratic Class Struggle. London, Boston, Melbourne, Henley: Routledge \& Kegan Paul.

Křížová, M. 2005. „Volání po skutečných ,dějinách celého světa'. Možnosti integrace mimoevropského prostoru do konceptu světových dějin." Příspěvek přednesený na workshopu Antropologie - Historie - Teorie. Praha, 17. 11. 2005. [Výukový materiál ke kurzu Historiografie Latinské Ameriky v akademickém roce 2009-2010].

Kuhnle, S. 2011. „International Modelling in the Making of the Nordic Social Security Systems." Pp. 65-81 in P. Kettunen, K. Petersen (eds.). Beyond Welfare State Models. Transnational Historical Perspectives on Social Policy. Cheltenham, Northampton: Edward Elgar. 
Lloyd, C. 2011. „The History and Future of Social Democratic Welfare Capitalism: From Modernization to the Spectres of Ultramodernity. “ Pp. 199-217 in P. Kettunen, K. Petersen (eds.). Beyond Welfare State Models. Transnational Historical Perspectives on Social Policy. Cheltenham, Northampton: Edward Elgar.

Markkola, P. 2011. „The Lutheran Nordic Welfare States.“ Pp. 112-118 in P. Kettunen, K. Petersen (eds.). Beyond Welfare State Models. Transnational Historical Perspectives on Social Policy. Cheltenham, Northampton: Edward Elgar.

Melby, K., A.-B. Ravn, B. Rosenbeck, C. C. Wetterberg. 2011. „What is Nordic in the Nordic Gender Model?“ Pp. 147-169 in P. Kettunen, K. Petersen (eds.). Beyond Welfare State Models. Transnational Historical Perspectives on Social Policy. Cheltenham, Northampton: Edward Elgar.

Michel, S. 2011. „Moving Targets: Towards a Framework for Studying Family Policies and Welfare States." Pp. 119-146 in P. Kettunen, K. Petersen (eds.). Beyond Welfare State Models. Transnational Historical Perspectives on Social Policy. Cheltenham, Northampton: Edward Elgar.

Nankoe, M. 2002. The Social Question and the Welfare State in the Modern World-System. Ph.D. Dissertation. Binghampton University. Ann Arbor: ProQuest Information and Learning Company.

Petersen, J. H. 2011. "Marketization and Free Choice in the Provision of Social Services. Normative Shifts 1982-2008. Social Democratic Lip Service as a Response to Problems of Legitimacy." Pp. 170-198 in P. Kettunen, K. Petersen (eds.). Beyond Welfare State Models. Transnational Historical Perspectives on Social Policy. Cheltenham, Northampton: Edward Elgar.

Petersen, K. 2011. „National, Nordic and Trans-Nordic: Transnational Perspectives on the History of the Nordic Countries." Pp. 41-64 in P. Kettunen, K. Petersen (eds.). Beyond Welfare State Models. Transnational Historical Perspectives on Social Policy. Cheltenham, Northampton: Edward Elgar.

Rákosník, J. 2009. „Sociální stát jako kategorie historického výzkumu.“ Historická sociologie/Historical Sociology 1 (1): 65-79.

Rákosník, J. 2010. Sovětizace sociálního státu: Lidově demokratický režim a sociální práva občanů v letech 1945-1960. Praha: Karolinum.

Rákosník, J., I. Tomeš a kol. 2012. Sociální stát v Československu: Právně-institucionální vývoj v letech 1918-1992. Praha: Auditorium.

Rodgers, D. T. 1998. Atlantic Crossings: Social Policy in a Progressive Age. Cambridge, London: Harvard University Press.

Weir, M., A. S. Orloff, T. Skocpol (eds.). 1988. The Politics of Social Policy in the United States. Princeton: Princeton University Press.

Wilensky, H. L. 1975. The Welfare State and Equality: Structural and Ideological Roots of Public Expenditures. Berkeley: University of California Press. 